\title{
Maternal Adaptation in the Role of Caring for and Rearing 12-Month-old Babies
}

\author{
Amanda Schöffel Sehn*,1 \\ Orcid.org/0000-0002-0897-9773 \\ Natália Luz Feeburg ${ }^{1}$ \\ Orcid.org/0000-0003-1665-7974 \\ Cesar Augusto Piccinini ${ }^{1}$ \\ Orcid.org/0000-0002-4313-3247 \\ Rita de Cassia Sobreira Lopes ${ }^{1}$ \\ Orcid.org/0000-0002-6433-1648
}

${ }^{1}$ Universidade Federal do Rio Grande do Sul, Porto Alegre, RS, Brasil

\begin{abstract}
This study aimed to investigate the maternal role of caring for and rearing 12-month-old babies based on Winnicott's concepts. Twenty-five primiparous mothers answered interviews about the baby's development and motherhood. Thematic analysis showed that the maternal role of caring for was marked by manifestations of dependence and independence, by the development transitions, and by maternal sensitivity to the signs and rhythm of the baby. Regarding the role of rearing, mothers reported different strategies when they needed to establish the baby's limits. They also had doubts about the best way to rear the baby, since he/she often opposed the maternal limits. In summary, at 12 months, the specificity of maternal role was related to the subtle adjustment of the mother to the more active rhythm of the baby, being emotionally available to his/her new discoveries, but also allowing his/her experiences of frustration.
\end{abstract}

Keywords: Child development, maternal role, caring, rearing.

\section{Adaptações Maternas Envolvidas na Função de Cuidar e Educar aos 12 Meses do Bebê}

\section{Resumo}

Este estudo teve como objetivo investigar a função materna de cuidar e de educar aos 12 meses do bebê, com base em conceitos winnicotianos. Participaram 25 mães primíparas, que responderam entrevistas sobre o desenvolvimento do bebê e sobre a maternidade. Análise temática evidenciou que a função de cuidar foi marcada pelas manifestações de dependência e independência, pelas transições no desenvolvimento, bem como pela sensibilidade materna frente aos sinais e ritmo do bebê. A função de educar envolveu diferentes estratégias adotadas pelas mães e houve relatos de dúvidas sobre a

* Mailing address: Rua Ramiro Barcelos, 2600, Sala 108 - Bairro Santa Cecília, Porto Alegre - RS, Brazil 90035 003. Phone: (51) 3308-5066. E-mail: amanda_sehn@hotmail.com. 
melhor forma de educar. Também foram relatadas reações de contrariedade do bebê diante dos limites maternos. Em síntese, aos 12 meses, a função materna parece estar relacionada à sutil adaptação da mãe ao ritmo mais ativo do bebê, estando emocionalmente disponível às suas novas descobertas, mas também permitindo a ele experiências de frustração.

Palavras-chave: Desenvolvimento infantil, função materna, cuidar, educar.

\section{Adaptaciones Maternas en la Función de Cuidar y Educar a los 12 Meses del Bebé}

\section{Resumen}

Este estudio tuvo como objetivo investigar la función materna de cuidar y de educar a los 12 meses del bebé. Participaron 25 madres primíparas, que respondieron entrevistas sobre el desarrollo del bebé y la maternidad. El análisis temático evidenció que la función de cuidar fue marcada por las manifestaciones de dependencia e independencia, las transiciones del desarrollo y pela sensibilidad materna frente a los señales y ritmo del bebé impregnaron el cuidar. La función de educar involucró diferentes estrategias adoptadas por las madres y hubo relatos de dudas sobre la mejor forma de educar, ya que a menudo el bebé esbozaba reacciones de contrariedad ante los límites maternos. En síntesis, a los 12 meses, la especificidad de la función materna está relacionada con la sutil adaptación de la madre al ritmo más activo del bebé, estando emocionalmente disponible a sus nuevos descubrimientos, pero también permitiéndole experiencias de frustración.

Palabras clave: Desarrollo infantil, función materna, cuidar, educar.

The maternal role plays a crucial part from the beginning of the baby's life (Winnicott, $1965 / 2011$ ), and it includes the tasks of caring for and rearing (Gomes, 2016; Henriques, Falbo, Sampaio, Fonte, \& Krause, 2015). From this viewpoint, the presence of a person responsible for the baby's care is indispensable in order to ensure his/her survival (Winnicott, 1965/2011). Despite Winnicott (1965/2011) originally having used the term "maternal role", one can understand that other caretakers, such as fathers, grandmothers and educators can assume the baby's care, performing the tasks of caring for and rearing. Nowadays new forms of relationship have been established in the family context, decentralizing the responsibility of those tasks beyond the maternal figure. Such a phenomenon is partly related to the work activities of both parents and particularly to the woman's return to work from maternity leave (Hook \& Wolfe, 2013; Murray, 2015).

However, many families still opt for a traditional arrangement, prioritizing maternal care in the first few years of the baby's life
(Berghammer, 2014; Murray, 2015) for a number of reasons, such as the parents' preference, availability and accessibility, as well as the family's financial resources (Coley, VotrubaDrzal, Collins, \& Miller, 2014). This still seems to be the predominant reality in Brazil, according to a research by the Maria Cecília Souto Vidigal Foundation (2017), which had access to 9.5 million Brazilian households with children from 0 to 3 years, based on the 2010 Demographic Census. Among the results, a highlight is that $89 \%$ of mothers were responsible for the child, with only $5 \%$ of the fathers performing that role in the sample. The research considered the person responsible for the child as the adult who lived in the same household and was involved in the decisions about the child's routine. In accordance with those results, the literature review from Vieira et al. (2014) on parenthood in Brazil revealed that a traditional division of parental parts still prevails, in which the father predominantly assumes responsibility for providing for the family, even if there is a desire for greater participation in child care. 
The initial years are an important period that has repercussions for life, since the basis for building the psyche and personality is established in infancy, as stressed by Winnicott (1965/2011) and evidenced in more recent studies (Brazelton, 2002; Murray, 2015; Osher, Cantor, Berg, Steyer, \& Rose, 2018). Specifically in the first year, expressive changes in child development related to physical and emotional growth occur (Brazelton, 2002; Stern, 1991). Particularly regarding emotional development, according to Winnicott (1965/2011), babies, with the help of maternal care, move toward growth, initially finding themselves in a stage of absolute dependence, which gradually becomes relative and advances toward independence. Due to the complexity involved in these stages, sometimes the baby's accomplishments bring out different feelings in mothers, which was verified in the study by Lopes et al. (2007), based on interviews with 25 primiparous mothers of 12-month-old babies. Among other results, mothers reported ambivalent feelings regarding the baby's development, oscillating between gratification and tiredness.

The baby's development accomplishments at that age group require an adaptation of the tasks of caretaking and rearing in order to deal with the moment's new acquisitions (Winnicott, 1965/2011), requiring, for instance, a more active stance from the caretaker in light of the baby's exploration of the environment. In that process, babies also start to send more active signals to the caretaker of what they need according to their age, and their development can be seen as an ally of the maternal role (Barbosa, Machado, Vilela e Souza, \& Scorsolini-Comin, 2010; Caron \& Lopes, 2014). This can be illustrated when, by acquiring the ability to walk, babies explore the environment with greater intensity, requiring that the caretaker accompany them in their explorations, whether by keeping them from falling or indicating that they can not put their fingers in sockets, for example (Sehn \& Lopes, in press). Thus, as babies grow, they show the adults their new discoveries and needs (Caron \& Lopes, 2014; Lopes et al., 2007).
In that regard, Mahler, Pine, and Bergman (1977) highlight the process of separationindividualization that occurs from the mother's presence and emotional availability to favor the baby's "psychological birth". This process starts around six months of age, intensifying around the 9th and 12th months, with the acquisition of mobility, when the babies start to crawl and physically distance themselves from the mother. The next highlight would be the free walk, in a vertical position; the moment babies start to explore the world around them and acquire the notion that they are separate from the mother. Thus, the importance of Mahler's contributions regarding child development can be stressed (Ribeiro \& Caropreso, 2018), with emphasis on the importance of maternal availability so that the child feels safe with the movements of getting closer and further, and consequently builds their own individuality (Bossi, Soares, Lopes, \& Piccinini, 2014).

Similarly, Winnicott (1971) states that child development, especially early in life, depends on a satisfactory environmental supply that is capable of facilitating the individual tendencies inherited, understood as the individual's innate potential to develop physically and emotionally. Recent studies have been pointing in that direction (Lucas, Richter, \& Daelmans, 2018; Osher et al., 2018), with emphasis on the promotion of parental practices that can contribute to the child's development (Lucas et al., 2018).

In that sense, taking care of a child involves the mother's sensitive adaptation to the baby's constantly-changing needs (Winnicott, 1965/2011). This adaptation process is characterized by being something natural, not based on formal knowledge, but that, instead, comes from maternal intuition and an augmented sensitivity that starts to develop during the pregnancy (Winnicott, 1965/2011). More specifically, caretaking is about catering to the baby's physical needs (such as bathing and changing diapers) as well as their emotional needs that may manifest very subtly, whether by mumbling, crying or through a gesture, for example. It should also be pointed out that 
these emotional needs may be fulfilled by the caretaker's presence, look, words and/or hold.

Throughout the child's development, besides caretaking, another maternal task that becomes equally important is rearing, which involves the constitution of boundaries, which takes place from the beginning of the motherbaby relationship, through the boundaries of the body (Winnicott, 1969/1993). In this sense, Winnicott (1969/1993) states that the child's acceptance of "no" happens in three stages, which do not necessarily imply an order and sequence. The first is about the caretakers' full responsibility to protect the baby from concrete dangers of the world. In that non-verbal moment, a sufficiently good mother is capable of fulfilling the baby's needs, thus avoiding that unexpected things happen to the child. Later, the caretakers should be able to allow babies to learn some of the dangers they are being protected from, when the "no" itself is said. This characterizes the second stage of the "no", the moment when reality is gradually presented to the baby (Winnicott, 1969/1993).

Finally, in the third stage come the explanations accompanying the "no", once the child has a basis for understanding what happens in the environment he/she is in (Winnicott, 1969/1993). There is also cooperation from the child in the moment the explanations emerge, which involves language. Therefore, the first form of rules and boundaries presented to the child is through caretaking and through the baby's dependence of that care, and after that initial period, morale is developed, when boundaries are established in a concrete way by the caretakers (Winnicott, 1969/1993).

Based on these considerations, it is possible to affirm that the maternal care - highly sensitive and predictable - offered to the baby early in life is fundamental to the constitution of the individual's psyche (Caron \& Lopes, 2014; Gomes, 2016), which allows for them to come to be (Winnicott, 1965/2011). In addition, it is due to caretaking that later on the child will be able to accept rules and boundaries, as a result from the "no's" said by their parents and other people. It can also be stressed that the dependence of care puts the baby in a position of vulnerability, both physical and emotional, bearing in mind that the absence or lack of essential care early in life can have repercussions on the child's development later on (Barbosa et al., 2010; Gomes, 2016; Henriques et al., 2015).

Those situations can be demanding on the caretaker, as pointed out by Caron and Lopes (2014) in a study that had the goal of following the development of the baby and the motherbaby relationship longitudinally, through the Bick method of observation (Bick, 1964), from the second week of pregnancy until the child reached three years of age. As a result, the unique course of mother-baby duos can be pointed out, marked by the complexity and authenticity of each relationship. In other words, each mother and their baby had a unique experience, in which they gradually got to know their child, and built themselves into the role of caretaker through trial and error. Although the first few months after delivery were described as the most intense, each age brought its own challenges. Beyond the labels of what it means to be a mother, the study enables an understanding that the relationship established between mother and baby is build along the way, being characterized as complex and non-linear (Caron \& Lopes, 2014).

Similar data were verified in a longitudinal case study with three mothers, with the goal of investigating the maternal experience in the role of caretaking in different moments of development (Sehn \& Lopes, in press). The mothers' reports revealed that the task of caretaking demands great maternal availability, being marked by overload and intense, ambivalent feelings. These feelings may impact the task of caring for the baby. For instance, when the mother is sleep-deprived and feeling tired and overwhelmed, the care given to the baby may be marked by impatience and the mother may have difficulty dealing with behaviors of tantrum or disobedience by the baby (Sehn \& Lopes, in press). Therefore, taking care of babies is a complex task, which may lead to anxiety and feelings difficult to deal with for the caretakers, whether in a family context 
(Caron \& Lopes, 2014; Gomes, 2016) or even in collective care facilities, such as daycare centers (Polli \& Lopes, 2017). Namely, regardless of the caretaking arrangement (family or daycare, for example), the role of caring for a baby is, in itself, demanding, which points to the importance of more investigation and understanding of this phenomenon (Caron \& Lopes, 2014).

In short, several of the aforementioned studies have been approaching the task of caretaking from a Winnicottian perspective, whereas rearing has not been researched to the same extent in that age group, for being considered a concern that arises in a later moment in development. However, it can be understood that both tasks (caretaking and rearing) are interlinked and take place from the very beginning of child development, even if performed with different intensities. In that sense, although many researches highlight the maternal role (Barbosa et al., 2010; Frota, Bezerra, Férrer, Martins, \& Silveira, 2011; Henriques et al., 2015), the challenges of caretaking and rearing in the family routine have been gaining less attention from authors, being explored more superficially (Andenaes, 2014). In light of the above, the goal of this study was to research the maternal adaptations involved in the role of caring for and rearing babies at 12-months-old, based on Winnicottian concepts.

\section{Method}

\section{Participants}

Twenty-five mothers participated in the study with their babies, 13 girls and 12 boys, who were approximately 12-months-old at the moment of the date collection and did not present health issues. The participants were aged between 20 and 37 ( $M: 27$ years-old; $S D: 10.95$ ), all of them being primiparous and living with the baby's father. The mothers had different levels of education, varying from incomplete elementary school to graduate school, and they were also in different socioeconomic levels. The mothers were part of a larger project called "Longitudinal Study of Porto Alegre: From pregnancy to school 1998-2012 - ELPA" (Estudo longitudinal de Porto Alegre: Da gestação à escola 19982012- ELPA, Piccinini, Tudge, Lopes, \& Sperb, 1998) and they were selected according to the following criteria: being a primiparous mother, having a 12-month-old baby at the time of data collection, living with the baby's father, and not being a teenage mother. In addition, cases with the complete data were given preference.

\section{Procedures and instruments}

This is a qualitative, cross-sectional research, with the goal of investigating the maternal adaptations involved in the role of caring for and rearing 12-month-old babies. The procedures followed the ones of the ELPA Project, and the families were already being monitored since pregnancy, and once the baby was 12-months-old, they were contacted again and invited to return and participate in the project. On that occasion, a meeting was scheduled at the family's residence or another place of the participants' preference, when the mother responded to the interviews foreseen for that phase of data collection. For this study, the data considered were from the "Interview on the motherhood experience and the development of the baby at 12 months", which investigates several themes of child development, the motherhood experience, and the participation of other caretakers and daycares. The "Interview on baby temperament at 12 months" was also included, investigating the parents' perception of the baby's temperament and it consists of several questions regarding feeding, sleeping, and sphincter control, as well as the baby's reactions to new situations. In the latter interview, only questions on feeding, sleeping and the baby's sphincter control were considered, not using the block of questions on temperament, as it is not the focus of this study.

Both interviews are structured, but were conducted in a semi-directed form, with interviewers having been guided to explore the mothers' answers. In addition to those instruments, this study used data from the "Demographic Data Form", filled out by the mother 
in the previous phase of the ELPA Project, to characterize the socioeconomic and education levels of the participants. All interviews were recorded and subsequently transcribed.

\section{Ethical Procedures}

The ELPA Project, which this study is a part of, was approved by the Federal University of Rio Grande do Sul (UFRGS) Ethics Committee (Resolution No. 2006596) and the Clinic Hospital of Porto Alegre (Resolution No. 98293).

\section{Data Analysis}

With the goal of researching the maternal adaptations involved in the role of caring for and rearing 12-month-old babies, a thematic analysis was carried out (Clarke \& Braun, 2013). After an exhaustive read of the material, the maternal reports were classified into three themes derived from the data and literature (Winnicott, 1965/2011):

1. Perceptions and maternal feelings faced with the baby's needs for care at 12 months: describes the adaptations in the care for the baby facing the development accomplishments at 12 months and the maternal perception of the baby's manifestations of (in)dependence;

2. Maternal role of caring for the baby at 12 months: deals with the specificities of the maternal role of caring for the baby at 12 months, considering the transitions in the baby's care and the pace of development;

3. Maternal role of rearing the baby at 12 months: involves the maternal strategies in the establishment of boundaries and the babies' reactions.

All interviews were read by the first two authors individually, which was the moment when the themes were defined and the vignettes were selected. After the selection, the pertinent reports were classified into the respective themes independently (agreement of 79.6\%) and in the cases where there was disagreement, a third researcher was consulted in order to achieve consensus. Each one of the themes is illustrated by maternal reports below.

\section{Results}

\section{Maternal Perceptions of the Baby's Needs for Care at 12 Months}

Initially the mothers' perceptions of the baby's needs for care at 12 months will be presented, in relation to the many accomplishments that take place in the first year of the baby's life, such as speech acquisition, learning to walk and a broader exploration of the environment. In that sense, the mothers stressed changes to caretaking moments such as bathing $(n=25)^{1}$, feeding $(n=24)$, diaper changing $(n=18)$ and changing clothes $(n=10)$. With regard to bathing, the vast majority of mothers $(n=20)$ reported their child liked the moment and used to play during it: " $\mathrm{He}$ loves bath time... When he gets in the bathtub he doesn't want to get out" (C8). Overall, there did not seem to be a resistance to bathing. However, some babies $(n=5)$ would cry when it was time to get out: "It's a fight to get out of the bath! ... I want to take him out, he'll hold to the sides of the tub, like this, and will not let go!' (C23). Yet it was noted that some babies $(n=3)$ did not want to be bathed while sitting and would try to stand up in the bathtub or to be bathed in the shower, like the parents: "She doesn't like to sit down for a bath, so when you try to get her in the bathtub, she will harden her feet, it is helpless" (C3). Some babies ( $n=4)$ showed interest in wanting to clean themselves: "Then she reaches for the soap, she wants to use it. ... She reaches for her shampoo bottle" (C7). Only one mother reported that her son did not like bathtime: "Now he's in a phase of not wanting to be bathed and get his hair washed. So when I step into the bathroom he starts crying" $(\mathrm{C} 22)$.

1 In order to facilitate the exposition of findings, as for the number of participants who submitted reports classified into each theme: one/some mothers: 1 to 6 ; many mothers: 7 to 12 ; most mothers: 13 to 18 ; the vast majority of/all mothers: 19 to 25 . This classification was adapted based on Hill et al. (2005). Ownership of the vignettes, on the other hand, was identified by the letter " $\mathrm{C}$ ", in reference to the research participants, followed by the case number. 
With regard to feeding, most mothers $(n=15)$ had difficulties because the child would refuse to eat in some moments: "Sometimes she doesn't want it, so when I get the food in her mouth, she will immediately spit it out" $(\mathrm{C} 1)$. This seems to also be associated to the fact that many mothers $(n=11)$ reported that the baby would not sit still for the meal, showing interest in walking around the environment and playing:

When I feed him I always have to have a toy... He will eat for a while in his chair and sometimes he will want to get out, other times he will eat a little more while sitting on my lap. (C19)

Many mothers $(n=8)$ identified manifestations that their child wanted to eat by themselves: "She is starting to learn to eat with her hand, but of course she makes a mess of it, right?!" (C13). Only two mothers mentioned their child was well-behaved during meals: "He is very wellbehaved. . . I think his behavior is great, he is not very messy, no" (C17).

Difficulty changing diapers was reported by most mothers $(n=15)$, indicating a more active behavior from the baby during that moment: "Kicks around, wants to turn over to the side . . and keeps rolling over" (C4). Three mothers reported that their child would play during diaper changes, usually with closeby objects: "Sometimes she stays still, others she wants to play with everything around, stand up and not care at all about the diaper" (C14). Only one mother described her child as collaborative in that moment: "When she sees it's time to change her diaper, she will go to her bedroom on her own when I say 'Let's change that diaper" (C15). Specifically with regard to changing clothes, many mothers $(n=8)$ reported difficulties, also referring to the fact that the baby was more active: "Oh, he moves all the time, he wants to turn to one side and the other" (C24). It should also be highlighted that two mothers stated their child would collaborate in the moment of changing clothes: "I think she collaborates to change clothes, today I was delighted, she helped me" (C14).

As to the manifestations of dependence and independence from mother and baby, most mothers $(n=17)$ mentioned some of the baby's behaviors that indicated dependence and independence. With regard to manifestations of the baby's dependence, many mothers $(n=8)$ reported being sought for attention and physical proximity: "He is always looking for me . . . Sometimes he just doesn't care, does not want any toys, just wants to hold tightly to my legs. And wants to touch the things I am handling" (C18). Many mothers $(n=8)$ also mentioned they could recognize in the baby's expression the desire not to move apart:

Oh, he cries, he feels it, you know? When I get home from work to shower, he will not let go of me, the entire time around him, does not let go, he comes crying, I have to fight to get out. $(\mathrm{C} 12)$

In that sense, some mothers $(n=6)$ felt their child was very clingy toward them: "I can barely do anything, Julia is very clingy, she is very dependent on me, you know" (C5).

As to manifestations of the baby's independence, some mothers $(n=4)$ stated their child could entertain themselves alone for some time: "Then plays for a good while and we just listen to it" (C11). Two mothers reported a greater distancing from the baby after acquiring moving skills:

When he was just a baby, could not walk, so it was just me, he/she would only stay on my lap, so I had a certain control, now I have lost control because I always have to chase him/her around. (C17)

With regard to manifestations of the mother's dependence and independence, there were some reports $(n=5)$ of concern in the moments of separation from the baby: "Oh... If I have to go out and leave her . . . I am constantly thinking about her... oh, 'I hope she is not crying! I hope she is playing!" (C20). Some mothers $(n=6)$ said they thought about their child and missed them when they were apart: "Yesterday when I got home it was four o'clock, and I was like 'Oh, where is my chubby baby.' .. . You think like that a lot..." (C21).

It was also observed that three mothers reported feeling the need to resume their professional life or have some personal time for themselves: 
What I notice the most is some of that 'me time'.... And that whole commitment thing, you know you have to do ... He cried, there is nothing else ... the child depends directly on you. (C19)

In addition, two mothers expressed concern to stimulate the child's independence: "I let her experiment and see the difficult things . . I know she [grandmother] protected me too much... And I would not like for her [baby] to go through that" (C3). Similarly, two mothers mentioned realizing how grown the child was: "And I said 'he is a big boy, you know, he is really a boy, we no longer have baby Inácio, we have a little boy at home" (C22).

\section{Maternal Role of Caring for the Baby at 12 Months}

With regard to the maternal role of caretaking, an initial highlight is on how mothers dealt with the main transitions in development, namely weaning ( $n=11)$, sleeping $(n=13)$, and toilet training $(n=4)$. Some mothers $(n=6)$ reported a reduction in breastfeeding, with a bigger interval between sessions, especially at night: "It was already the sixth month, I didn't have much milk left and he had already been making faces. So it was a very natural, very physiological thing, really" (C19). Whereas three mothers reported they stopped breastfeeding altogether: "It was her decision. . . . The day she turned one-yearold, she nursed one last time and stopped" (C5). Some mothers $(n=6)$ declared using a nursing bottle and three chose exclusive maternal breastfeeding. Moreover, three mothers stated their child had difficulty waiting for the bottle to be ready: "She is not good at waiting. She goes crazy for her bottle, so if she sees it she starts crying and she keeps crying until it cools down" (C14). Another aspect mentioned by two mothers was the difficulty in the weaning process:

At night I did not want to [breastfeed], right? But he just will not let go of the breast for anything... He gets up and stays there waiting for me to get him out of the crib. Then what? What else am I going to do? (C17)
With regard to sleep, half the mothers $(n=13)$ described changes, such as the babies starting to sleep by themselves: "I laid him in the crib, but placed the crib in my bedroom. Then after six months, I decided 'Well, I have to put it in his [bedroom], right?"” (C2), or returning to the parents' bed: "Before she would lay down, sit up, lay down again, then she would kick around and cry, you know? It was a very agitated sleep. Once we laid her in bed [with the parents], no. She sleeps well" (C16). Regarding the place where the babies slept, some mothers $(n=4)$ stated the babies slept in their own room, in bed with the parents $(n=5)$, and in some cases $(n=4)$ the babies slept in a crib in the parents' bedroom - many times sleeping some of the time the parents' bed. With regard to toilet training, some mothers $(n=4)$ reported their child had already begun training with the potty:

He has the potties, I show him he has to use it ... 'You have to go poo poo in the funny car!' and he will go 'Poo poo! Poo poo!' . . . But he doesn't want to! He's scared of the potty. Maybe he's also just really young, right? Yeah. I have to play with him in the potty. (C23)

Still on the topic of the maternal role of caretaking, the reports involving maternal sensitivity to the pace and the signs of the baby should be highlighted. That aspect was associated to recognizing the baby's different types of cry, with the vast majority of mothers $(n=23)$ mentioning that the difference between the cries for sleep and food, for example, was noticeable: "When it's hunger, it's not really a cry it's more like a scene, you know, it's not a cry, when he really is in pain he cries until tears come out" (C12).

Sensitivity was also identified through the recognition of the baby's expressions by many mothers $(n=9)$, such as realizing when the child would get angry, bothered, or have some sort of difficulty: "I leave all the pacifiers in the corner for her, but she looks for them and can't find them in that position and can't turn around, she grumbles, so I go there and turn her, you know" (C25). According to the mothers' statements, 
during playtime mothers were also attentive to the baby's pace and signs. In that sense, most mothers $(n=18)$ reported getting involved playing with the child, who also engaged in the activity: "Oh, now he plays, he assembles, he has a tricycle he likes to be pulled around in, he enjoys climbing us to play horsey, climbing the sofa and having us hold him" (C6). Among games, some mothers $(n=5)$ pointed out imitation behavior in the interaction: "I do something, she notices and says the same thing right after that. In a matter of seconds, she learns like that, she watches you, sees how you do it and does exactly the same thing" $(\mathrm{C} 21)$.

Other aspects that demonstrate mothers' sensitivity to the baby refer to respecting the child's time and wishes $(n=6)$ : "It's like the moments we both have. If I'm fine, I'll go out with her, take a walk, you know... If I'm not well or she's not well, we stay home" (C16); as well as the pace of development $(n=3)$ : "I used to say, you know, that at one-year-old he had to be walking . . . Then later, with time I realized that was silly of me" $(\mathrm{C} 2)$. Mothers' sensitivity was also illustrated by the recognition of characteristics that were attributed to being the baby's personality $(n=4)$ : "I feel like that's how she's like, she doesn't like me to yell at her, doesn't like loud noises. . . It's more emotional, I feel like she doesn't like it" (C3); and by noticing small development achievements $(n=2)$ : "Each day is a different discovery . . . he tries to say 'dad', say 'mom', tries to discover things" (C10). Although mothers show sensitivity to the baby's pace and signs, there was also mention to the struggles and feelings toward motherhood:

I used to go into deep sleep and now I only go into light sleep. Because even if you're sleeping, the smallest cry and you get up, so, I mean, you don't have that whole straight night just for yourself. . . . So it's tiring, it really is. (C5)

\section{Maternal Role of Rearing a Baby at 12 Months}

With regard to the maternal role of rearing, an initial highlight would be the different strategies and feelings reported by mothers when establishing boundaries to the child. Among the strategies used, most mothers $(n=18)$ declared only making verbal requests: "Sometimes I find it cute and funny, I'll just look, but other times I get mad: "No, you will not do that"' (C23). Some mothers $(n=4)$ also sought to explain to the child the reason for the boundary:

When I speak seriously and look her in the eye, once, twice, the third time she gets it [understands] . . . Back home I didn't take any objects out of the house, I tell her she can't touch it and explain that she'll get hurt. (C25)

On the other hand, many mothers $(n=10)$ described that in certain moments they ended up allowing the child to explore: "I try to teach her things, by explaining, then there comes a time I see it's not working so I quit or say, 'oh but also, like, no . . . Can it really not be done?"” (C13). It was also possible to identify that some mothers $(n=6)$ used the physical restriction of the baby's environment as a strategy to establish boundaries: "Yeah, her room really is her territory, over there I don't mind, in the living room of course you can't avoid it and say 'Oh, don't touch this or that'" (C4). Only two mothers used shifting the child's attention to another activity as a strategy: "It's exactly the things we say 'no' to that he'll touch. So usually we try to shift it to something else" (C2). Three mothers reported using physical restraint to keep the child from touching something they were not meant to: "If he is touching something he's not supposed to, I'll hold [him] and say 'you can't do that'. I do it very peacefully and he responds" (C22). Lastly, another strategy used by many mothers $(n=7)$ as a way to establish boundaries was physical punishment: "I'm really not. I say 'no, don't touch it, don't do it', I cuss, but I slap her hands, so she learns she can't touch it, but she won't obey" (C15).

As to the feelings faced by establishing boundaries, many mothers $(n=8)$ had doubts and concerns about how to teach the child:

Many times I'll ask myself 'Will I be able to pass this on to him, teach this, will he learn it well, what he can and can't do, what is dangerous'... Especially, like, these 
doubts, you know, will this work out or not.

Am I doing a good job? (C11)

Still on the role of rearing, one highlight is the maternal perception of the baby's reaction to the establishment of boundaries. A manifestation often reported by most mothers $(n=13)$ was the baby's madness facing a rejected request: "She is mad, she'll do anything to get what she wants. She screams, she cries, she lays on the floor..." (C5). Another response reported by many mothers $(n=11)$ was the child's intense cry faced with situations of frustration with a boundary: "When he gets really upset, then he'll really cry, first the tears starts to come out then he'll let his voice out, he cries silent and then, then that one is really a cry of feeling" (C6). On the other hand, some mothers $(n=4)$ mentioned their child would react with a soft cry, which they considered a grumble: "He's very calm, very quiet, but then he loses his patience, you know. . . . We won't let him do something and then... he grumbles" (C10). Many mothers $(n=7)$ also reported that the baby would protest when given a boundary, whether by screaming or fighting:

And she doesn't cry, she screams! . . I'll say: 'Don't scream, stop it, you don't have to scream!' and she'll scream even more. And if she's mad and we look at her, she gets mad, screams even more, we can't even look at her! (C20)

Aggressive reactions, including kicks and bites, for example, were also reported by some mothers $(n=5)$ : "She is very intense in her manifestations . . . she protests, she kicks, she spits" (C9). Another behavior pointed out by many mothers $(n=8)$ was the babies' selfaggression. When they were denied something or were faced with a boundary, these babies used to hit their own bodies, in a way they could hurt themselves: "If I didn't hold her, she started hitting her head... Against the wall, she would hit her head until I held her" (C1). Moreover, only one mother mentioned her child would repeat the 'no' when she was given a boundary: "She says 'no', she doesn't cuss or anything, Just says "no"' (C7).

\section{Discussion}

Specific aspects of the maternal role of caretaking and rearing the baby at 12 months were highlighted from the data analysis. Overall, it was possible to identify the mother's adaptation according to the child's changes in development, as verified by other researches (Barbosa et al., 2010; Lopes et al., 2007). In this sense, the babies in this study were more active in comparison to the previous months, with a greater expressiveness and exploration of the environment, which is in accordance with the field's literature (Brazelton, 2002; Lopes et al., 2007). In addition, the babies' more active stance reiterates the importance of the mother's adaptation to their ever-changing needs (Winnicott, 1965/2011). The data suggest that this adaptation may involve a higher tolerance for the baby's activity day-to-day, such as allowing the child to stand or explore objects during bathtime.

The development accomplishments were also associated to the adaptation in maternal care of the baby, demonstrating greater difficulty in moments of feeding and diaper changing, for instance, as mentioned by most mothers in this study. In that sense, the baby was more participative during the interaction with the mother, making his/her wishes prevail in some moments, such as denying the food offered or staying in a different position than the one the mother put them on, which also demanded a more active stance from the mother. According to Winnicott (1964/1982b), this greater independence shown by the baby is a result of the development of a sense of safety, facilitated by the exercise of the caretaking role.

The adaptations in the role of caretaking stemming from the baby's development were also observed through the manifestations of dependence and independence, understood not only as a movement from the baby but also from the mother. In other words, initially the mother needs to make herself available so the baby builds his/her own psyche, then it is important that she removes herself from that place of, at 
first absolute and later relative dependence (Winnicott, 1965/2011). That movement is demanding (Caron \& Lopes, 2014), since being able to fail, as well as allowing the baby to have experiences of frustration and discontinuity can cause mixed feelings in mothers (Barbosa et al., 2010; Lopes et al., 2007; Zanatta \& Pereira, 2015).

In this study, the baby's accomplishments also contributed to the mother removing herself from that place of dependence, since there was already a greater autonomy in the baby's ability to move, due to the acquisition of walk, allowing for an exploration of the environment. In addition, as they grow, babies can express themselves with regard to their wishes and needs, through cries, gestures and mumbles, indicating when they needed attention (by following the mother, for example) or when they wanted to be alone (seeking an activity/game in isolation), as observed in this study. However, even though in that moment of relative dependence the maternal investment in the baby is still fundamental, it is no longer necessary that the mother lend her body to the baby, as she did in the absolute dependence (Winnicott, 1965/2011), enabling her to leave the place of indiscrimination with the baby that characterized the previous stage (Caron \& Lopes, 2014).

The results in this study also revealed that the babies' walk toward greater independence brings new transitions, such as weaning and toilet training. While there was a maternal concern in initiating these transitions as development advanced, the baby also started to put himself/ herself in this relationship, actively showing their needs to the mother (Winnicott, 1964/1982b).

In that sense, the different maternal accounts of weaning presented in this study may be related to the way mother and baby experienced breastfeeding from the start, as pointed out by Winnicott $(1964 / 1982 a)$. Especially in the baby's first year, breastfeeding may be a stressful experience for the mother (Rapoport \& Piccinini, 2011), which was identified in some of the mothers' reports in this study. In that relation, weaning has also been identified as a difficult transition moment, due to the maternal anxiety regarding the nutritional aspects of breastfeeding (Rapoport \& Piccinini, 2011), as well as the emotional demands of the motherbaby relationship (Winnicott, 1964/1982a), both situations illustrated in the mothers' reports in this study. In addition, weaning may be felt as one of the baby's necessities, since new experiences are presented to him/her (Winnicott, 1964/1982b). In that scenario, it may be difficult for the mother to separate from the baby in the same intensity the baby needs her to separate from him/her. In regard to sleep, a transitional moment typical of that age group was observed (Rudzik \& Ball, 2016), in which most babies started sleeping by themselves, although some continued sleeping in the same bed or bedroom as the parents.

These transitions are associated to the fact that in the first year of life, the "self" is being built, allowing movements of approximation and separation from the baby in relation to his/her caretakers (Mahler et al., 1977). This enables the baby to sleep alone, for example, or be apart from the mother for a longer time without the need for breastfeeding, as verified in the maternal reports. Similar situations were observed in this study, related to the baby's manifestations of dependence and independence, in which the moments of separation were reported with greater difficulty by the mothers, for they were concerned, questioning whether or not their child had the capacity to be fine without them. Nevertheless, the maternal presence is important for the child's emotional reestablishment (Mahler et al., 1977), as highlighted by Bossi et al. (2014) in a study that investigated the parents' feelings and reactions to the baby's adaptation to daycare.

The maternal adaptation in the role of caretaker was described as a demanding task, which caused different feelings in mothers, who were happy to see the child's growth, while also lamenting the loss of that baby being more dependent on their presence. These aspects were also observed in the study by Lopes et al. (2007), which investigated the maternal feelings 
regarding the child's development, among which ambivalent feelings stood out, in light of the satisfaction for the baby's accomplishments at 12 months and the reported exhaustion from the demands of the moment.

In that sense, the experience of taking care of a baby enables the mother to have a greater knowledge about the child's development (Al-Maadadi \& Ikhlef, 2015), which can help reduce the feelings of concern. In addition, it is expected that the mother identify with the baby (Winnicott, 1969/1993) at the same time she differentiates herself from the child, assuming a stance of emotional maturity (Barbosa et al., 2010). Despite the difficulties faced to reduce dependence, some mothers in this study demonstrated the wish to leave that place and resume to exploring new spaces as a woman, such as going back to work. In accordance with that data, an ethnographic study by Murray (2015), which investigated the process of becoming a mother with 16 Chilean women identified that middle class mothers tended to go back to work after the baby turned six months, because the mothers started to feel fatigued with the domestic routine and opted to resume their personal projects.

The caretaking role also demanded that the mothers in this study be sensitive to the baby's signs and pace. In that sense, manifestations through cry were understood by the mothers as signs of the baby's hunger and discomfort, for example. Such aspects indicate that one of the parameters of maternal care is being attentive to the baby's signs and pace, illustrating that mothers seemed to understand the baby's needs and fulfill them, even if they were not expressed verbally (Winnicott, 1964/1982c). Regarding mother-baby communication, there is evidence that all maternal enunciation is preceded or followed by the baby's signals, in the attempt to engage him/her in dialogues, with the mothers seeking to appropriate the baby's manifestations of communication and respond to them according to the meaning and interpretation they attribute to those actions (Mendes \& Pessôa, 2013).

Another indicator of the caretaking role associated to the maternal sensitivity in that age group was the interaction through games, reported by the mothers in this study. Another highlight was how much sensitivity presumes a psychic intimacy, derived from a deeper level of relationship. According to the reports, imitation games with the baby were common, which seemed to contribute to the emergence of the symbolic capacity, as well as to providing safety to the baby to explore objects and spaces, as stressed by Winnicott $(1964 / 1982 c)$ and corroborated by other studies (Frota et al., 2011; Gomes, 2016).

Another highlight is the role of rearing, which is related to the cares offered to the baby early in life, bearing in mind that once the baby was around 12 months, establishing boundaries also included a verbal stance from the caretakers (Winnicott, 1969/1993). Namely, the mother must indicate to the baby what he/ she can or cannot do and explain why certain actions are not allowed, which many times is a difficult task (Zanetti \& Gomes, 2009). That moment is described by Winnicott (1969/1993) as the third stage of saying "no" and was verified in the maternal reports in this study, where verbal requests were the resource most used to establish boundaries, followed by restriction of the physical environment. Thus, gradually, the parents' caretaking and then rearing allow for the insertion of the baby in the social world (Winnicott, 1969/1993).

The field's literature also stressed that the mothers' feelings of concern and doubt over the best way to rear the child and/or how to act the moment they need to show the baby that what he/she wants is not possible (Patias, Siqueira, \& Dias, 2013; Zanetti \& Gomes, 2009), which was also corroborated by the mothers' reports in this study. That might be related both to the maternal concern of frustrating the child and the baby's reactions to being given that boundary (Zanetti \& Gomes, 2009). In this sense, according to Winnicott (1963/1983), the baby manifests opposite and completely independent feelings of approval and disapproval, which are shown to the mother and must be considered.

Manifestations of madness, intense crying, protest through complaints and self-aggression 
were also resources the babies used in the face of "no's", reported by many mothers in this study. In part, those reactions from the baby may be understood based on the moment of development they found themselves in, since around 12-months-old the baby understands the world from his/her point of view, as if things revolved around them, which makes it difficult to be denied something and partially explains their reactions to the maternal boundaries (Brazelton, 2002; Stern, 1991). Moreover, the establishment of boundaries is also related to the baby's new accomplishments, such as exploring the environment and the fact that the baby is more active, as the mothers in this study mentioned. Consequently, the baby starts to demand from the adult a more active stance as well, including as an organizer at this moment of discoveries. Although the issues related to rearing in that age group are not as frequent in literature, compared to caretaking, it does not mean they are less intense or less important. It should be pointed out that this role causes mothers to question themselves and is extremely important to child development, as verified.

In that sense, this study makes an important contribution, as it discusses the adaptation in the maternal role of caring for and rearing small children, a relevant theme to parents and caretakers that is not often investigated in the 12-month age group (Zanetti \& Gomes, 2009). It can be affirmed from this study that these tasks are built in the mother-baby relationship, which starts very early and transforms over time, based on the child's development accomplishments. Specifically with regard to rearing, the results indicate that when the baby learns to walk and explores the environment more actively, the boundary that was first related to physical care starts to have a verbal outline, through maternal requests, such as "don't touch it", "careful", among others. Those are maternal indications that protect the baby from possible dangers in the environment. For that reason, in this moment of development the mother's (or caretaker's) stance also becomes more active and demanding, both physically and emotionally, because at times, since the baby does not understand "no", they continue their exploration, with the possibility of putting themselves in jeopardy.

Finally, some aspects may be seen as limitations of this study, such as the fact that only traditional families were interviewed, in which the mother was the main caretaker of the baby. That choice was made because the data in this study are part of a larger longitudinal study, with the goal of investigating the subjective and behavioral aspects of father-mother-baby interactions, as well as the child's daily activities in their usual contexts. In addition, families with traditional settings were selected for still representing a great part of Brazilian families (Maria Cecília Souto Vidigal Foundation, 2017). In this sense, we suggest future studies investigate different family settings and involve a larger diversity of caretaking arrangements and family members. Overall, the roles of caring for and rearing are understood to be interlinked throughout development, being built in partnership with the baby, according to the pace of each duo. In light of that, we also suggest that studies involving rearing in the first year of the child's life be broaden, since it is a task performed by the caretakers from very early on and is accompanied by doubts and concerns.

In summary, at 12-months-old, the specificity of the role of caretaker is in the mother's subtle adaptation to the baby's more active pace, who starts to manifest behaviors of independence. In this sense, perhaps the greatest adaptation that age group demands is an internal movement from the mother so that she allows and offers support for the baby to grow and go through the necessary transitions to emotional maturity. It is a demanding task, since it demands that the mother be physically and emotionally available to the baby's new discoveries while at the same time allowing them experiences of frustration. Thus, the mother's capacity to identify with the baby should be reiterated so that the maternal role is performed as to contribute to the development accomplishments.

As to rearing, from this study it was possible to identify the doubts and concerns that permeate 
mothers in this complex and seldom discussed task at 12-months-old. It was also verified that mothers use different resources, among which verbal requests and, in some cases, restriction of the physical environment were highlighted. Therefore, although only mothers were contacted, from these data it is possible to assume that the challenges and demands of the roles of caring for and rearing can also be experienced by other caretakers, whether in the family context or in collective care. In addition, giving a voice to the difficulties found in the caretaker's journey, especially in the tasks of caring for and rearing, becomes relevant, as a way to demystify the experience of an idealized maternity.

\section{Authors' Contributions}

Substantial contribution in the concept and design of the study: Amanda Schöffel Sehn and Natália Luz Feeburg concepted and designed the study supervised by Rita de Cassia Sobreira Lopes.

Contribution to data collection: Cesar Augusto Piccinini and Rita de Cassia Sobreira Lopes concepted the project and contributed supervising the data collection.

Contribution to data analysis and interpretation: Amanda Schöffel Sehn and Natalia Luz Feeburg analyzed and interpreted the data.

Contribution to manuscript preparation: Amanda Schöffel Sehn and Natalia Luz Feeburg prepared the manuscript and wrote the text.

Contribution to critical revision, adding intelectual content: All the authors contributed to the critical revision, especially, Rita de Cassia Sobreira Lopes and Cesar Augusto Piccinini.

\section{Conflicts of interest}

The authors declare that they have no conflict of interest related to the publication of this manuscript.

\section{References}

Al-Maadadi, F., \& Ikhlef, A. (2015). What mothers know about child development and parenting in Qatar: Parenting cognitions and practices.
The Family Journal: Counseling and Therapy for Couples and Families, 23(1), 65-73. doi: 10.1177/1066480714555669

Andenaes, A. (2014). The task of taking care of children: Methodological perspectives and empirical implications. Child and Family Social Work, 19, 263-271. doi: 10.1111/j.13652206.2012.00897.x

Barbosa, F. A., Machado, L. F. V., Vilela e Souza, L., \& Scorsolini-Comin, F. (2010). Significados do cuidado materno em mães de crianças pequenas. Barbarói, 33, 28-49. Retrieved from http://pepsic.bvsalud.org/scielo.php?script $=$ sci arttext\&pid=S0104-65782010000200003

Berghammer, C. (2014). The return of the male breadwinner model? Educational effects on parents' work arrangements in Austria, 19802009. Work, Employment and Society, 28(4), 611-632. doi: 10.1177/0950017013500115

Bick, E. (1964). Notes on infant observation in psychoanalytic training. In A. Briggs \& D. Meltzer (Eds.), Surviving space: Papers on infant observation (pp. 37-54). London: Karnac Books

Bossi, T. J., Soares, E., Lopes, R. C. S., \& Piccinini, C. A. (2014). Adaptação à creche e o processo de separação-individuação: Reações dos bebês e sentimentos parentais. Psico (PUCRS), 45(2), 250-260. Retrieved from http:// revistaseletronicas.pucrs.br/ojs/index.php/ revistapsico/article/view/16283/11715

Brazelton, T. B. (2002). Momentos decisivos do desenvolvimento infantil. São Paulo, SP: Martins Fontes.

Caron, N. A., \& Lopes, R. C. S. (2014). Aprendendo com as mães $e$ os bebês sobre a natureza humana e a técnica analítica. Porto Alegre, RS: Dublinense.

Clarke, V., \& Braun, V. (2013). Teaching thematic analysis: Overcoming challenges and developing strategies for effective learning. The Psychologist, 26 (2), 120-123. Retrieved from http:/thepsychologist.bps.org.uk/volume-26/ edition-2/methods-teaching-thematic-analysis

Coley, R. L., Votruba-Drzal, E., Collins, M., \& Miller, P. (2014). Selection into early education and care settings: Differences by developmental period. Early Childhood Research Quarterly, 29, 319-332. doi: 10.1016/j.ecresq.2014.03.006 
Frota, M. A., Bezerra, J. A., Férrer, M. L. S., Martins, M. C., \& Silveira, V. G. (2011). Percepção materna em relação ao cuidado e desenvolvimento infantil. Revista Brasileira em Promoção da Saúde, 24(3), 245-250. doi: 10.5020/18061230.2011.p245

Gomes, S. (2016). "Eu vi que você viu que eu vi": A tríplice hélice narcísica no pensamento clínico de D. W. Winnicott. Tempo Psicanalítico, 48(1), 9-28. Retrieved from http://pepsic.bvsalud.org/ scielo.php?script $=$ sci_arttext\&pid $=$ S0101$48382016000100002 \& \operatorname{lng}=p t \& t \operatorname{lng}=p t$

Henriques, M. S. M. T., Falbo, A. R., Sampaio, M. A., Fonte, M. L. A., \& Krause, D. F. (2015). $\mathrm{O}$ exercício da função materna em mães de filhos obesos na perspectiva da psicanálise. Revista Latinoamericana de Psicopatologia Fundamental, 18(3), 461-475. doi: 10.1590/1415-4714.2015v18n3p461.4

Hill, C. E., Knox, S., Thompson, B. J., Williamns, E. N., Hess, S. A., \& Ladany, N. (2005). Consensual qualitative research: An update. Journal of Counseling Psychology, 52(2), 1-27. Retrieved from http://epublications.marquette.edu/cgi/ viewcontent.cgi article $=1017 \&$ context $=$ edu fac

Hook, J. L. \& Wolfe, C. M. (2013). Parental involvement and work schedules: Time with children in the United States, Germany, Norway and the United Kingdom. European Sociological Review, 29(3), 411-425. doi: 10.1093/esr/jcr081

Lopes, R. C. S., Oliveira, D. S., Vivian, A. G., Bohmgahren, L. M. C., Piccinini, C. A., \& Tudge, J. R. H. (2007). Sentimentos maternos frente ao desenvolvimento da criança aos 12 meses: Convivendo com as novas aquisições infantis. Psicologia: Teoria e Pesquisa, 23(1), 5-15. doi: 10.1590/s0102-37722007000100002

Lucas, J. E., Richter, L. M., \& Daelmans, B. (2018). Care for child development: An intervention in support of responsive caregiving and early child development. Child: Care, Health and Development, 44(1), 41-49. doi: 10.1111/ cch. 12544

Mahler, M., Pine, F., \& Bergman, A. (1977). O nascimento psicológico da criança. Rio de Janeiro, RJ: Zahar.

Maria Cecília Souto Vidigal Foundation. (2017). Primeiríssima infância - Creche: Necessidades $e$ interesses de familiares e crianças. São
Paulo, SP: Author. Retrieved from https:// issuu.com/fmcsv/docs/livro_ibope interativo final $/ 24$ ?ff $=$ true $\&$ e $=3034920 / 55030073$

Mendes, D. M. L. F., \& Pessôa, L. (2013). Comunicação afetiva nos cuidados parentais. Psicologia em Estudo, 18 (1), 15-25. doi: 10.1590/S1413-73722013000100003

Murray, M. (2015). Back to work? Childcare negotiations and intensive mothering in Santiago de Chile. Journal of Family Issues, 36(9), 11711191. doi: 10.1177/0192513X14533543

Osher, D., Cantor, P., Berg J., Steyer, L., \& Rose, T. (2018). Drivers of human development: How relationships and context shape learning and development. Journal Applied Developmental Science, 1(1), 1-31. doi: 10.1080/10888691.2017.1398650

Patias, N. D., Siqueira, A. C., \& Dias, A. C. G. (2013). Práticas educativas e intervenção com pais: A educação como proteção ao desenvolvimento dos filhos. Mudanças - Psicologia da Saúde, 21(1), 29-40. doi: 10.15603/2176-1019/mud. v21n 1 p29-40

Polli, R. G., \& Lopes, R. C. S. (2017). Do que o bebê precisa? A função de cuidar na perspectiva das educadoras de berçário. Interação em Psicologia, 21(2), 157-166. doi: 10.5380/psi. v21i 2.47810

Piccinini, C. A., Tudge, J. R., Lopes, R. C. S., \& Sperb, T. M. (1998). Estudo Longitudinal de Porto Alegre: Da Gestação à Escola, 1998-2012 - ELPA. Unpublished manuscript, Instituto de Psicologia, Universidade Federal do Rio Grande do Sul, Porto Alegre, RS, Brazil.

Rapoport, A., \& Piccinini, C. A. (2011). Maternidade e situações estressantes no primeiro ano de vida do bebê. Psico-USF, 16(2), 215-225. doi: $10.1590 / \mathrm{S} 1413-82712011000200010$

Ribeiro, A., \& Caropreso, F. (2018). Pesquisa em psicanálise com bebês e crianças pequenas: $\mathrm{O}$ que Margaret Mahler nos deixou como modelo. Mental, 12(22), 18-34. Retrieved from http:// pepsic.bvsalud.org/scielo.php? script $=$ sci arttext\&pid=S1679-44272018000100003\&lng= pt\&tlng=pt

Rudzik, A. E. F., \& Ball, H. L. (2016). Exploring maternal perceptions of infant sleep and feeding method among mothers in the United Kingdom: A qualitative focus group study. Maternal 
and Child Health Journal, 20(1), 33-40. doi: 10.1007/s10995-015-1798-7

Sehn, A. S., \& Lopes, R. C. S. (in press). A vivência materna da função de cuidar no período de dependência. Manuscript submitted for publication.

Stern, D. (1991). Diário de um bebê: O que seu filho vê, sente e vivencia. Porto Alegre, RS: Artes Médicas.

Vieira, M. L., Bossardi, C. N., Gomes, L. B., Bolze, S. D. A., Crepaldi, M. A., \& Piccinini, C. A. (2014). Paternidade no Brasil: Revisão sistemática de artigos empíricos. Arquivos Brasileiros de Psicologia, 66(2), 36-52. Retrieved from http:// www.redalyc.org/html/2290/229031583004/

Winnicott, D. W. (1983). Moral e educação (I. C. S. Ortiz, Trans.). In D. W. Winnicott, $O$ ambiente e os processos de maturação (pp. 121-140). Porto Alegre, RS: Artmed. (Original work published in 1963)

Winnicott, D. W. (1971). O papel de espelho da mãe e da família no desenvolvimento infantil (J. O. A. Abreu e V. Nobre, Trans.). In D. W. Winnicott, $O$ brincar e a realidade (pp. 175-186). Rio de Janeiro, RJ: Imago

Winnicott, D. W. (1982a). O Desmame (A. Cabral, Trans.). In D. Winnicott, A criança e seu mundo (pp. 89-94). Rio de Janeiro, RJ: Guanabara Koogans. (Original work published in 1964)

Winnicott, D. W. (1982b). Primeiras experiências de independência (A. Cabral, Trans.). In D. Winnicott, A criança e seu mundo (pp. 189195). Rio de Janeiro, RJ: Guanabara Koogans. (Original work published in 1964)
Winnicott, D. W. (1982c). Necessidades das crianças de menos de cinco anos (A. Cabral, Trans.). In D. Winnicott, A criança e seu mundo (pp. 203213). Rio de Janeiro, RJ: Guanabara Koogans. (Original work published in 1964)

Winnicott, D. W. (1993). Dizer "não" anos (A. Cabral, Trans.). In D. Winnicott, Conversando com os pais (pp. 27-48). São Paulo, SP: Martins Fontes. (Original work published in 1969)

Winnicott, D. W. (2011). O relacionamento inicial entre uma mãe e seu bebê (M. B. Cipolla, Trans.). In D. W. Winnicott, A família $e o$ desenvolvimento individual (pp. 21-28). São Paulo, SP: Martins Fontes. (Original work published in 1965)

Zanatta, E., \& Pereira, C. R. R. (2015). "Ela enxerga em ti o mundo": A experiência da maternidade pela primeira vez. Temas em Psicologia, 23(4), 959-972. doi: 10.9788/TP2015.4-12

Zanetti, S. A. S., \& Gomes, I. C. (2009). A ausência do princípio de autoridade na família contemporânea brasileira. Psico (PUC$R S), \quad 40(2)$, 194-201. Retrieved from http:// revistaseletronicas.pucrs.br/fo/ojs/index.php/ revistapsico/article/view/3726/4532
Received: 10/10/2017

$1^{\text {st }}$ revision: $28 / 01 / 2018$

$2^{\text {nd }}$ revision: $12 / 04 / 2018$

$3^{r t}$ revision: $15 / 07 / 2018$

$4^{r t}$ revision: $25 / 09 / 2018$

Accepted: 28/09/2018

(cc) BY 1 (C) The Author(s), 2018. Open Access. This article is distributed under the terms of the Creative Commons Attribution 4.0 International License (http://creativecommons.org/licenses/by/4.0/), which permits unrestricted use, distribution, and reproduction in any medium, provided you give appropriate credit to the original author(s) and the source, provide a link to the Creative Commons license, and indicate if changes were made. 